\title{
Gigantic lion, Panthera leo, from the Pleistocene of Natodomeri, eastern Africa
}

\author{
Fredrick K. Manthi, ${ }^{1}$ Francis H. Brown, ${ }^{2, \dagger}$ Michael J. Plavcan, ${ }^{3}$ and Lars Werdelin ${ }^{4 *}$ \\ ${ }^{1}$ Department of Earth Sciences, National Museums of Kenya, Museum Hill, P.O. Box 40658-00100, Nairobi, Kenya 〈fkmanthi@museums.or.ke〉 \\ ${ }^{2}$ Department of Geology and Geophysics, University of Utah, Salt Lake City, UT 84112-0102, USA 〈frank.brown@utah.edu〉 \\ ${ }^{3}$ Department of Anthropology, University of Arkansas, Fayetteville, AR 72701, USA 〈mplavcan@uark.edu〉 \\ ${ }^{4}$ Department of Palaeobiology, Swedish Museum of Natural History, Box 50007, S-104 05 Stockholm, Sweden〈lars.werdelin@nrm.se〉
}

\begin{abstract}
The partial skull of a lion from Natodomeri, northwest Kenya is described. The Natodomeri sites are correlated with Member I of the Kibish Formation, dated to between $195 \mathrm{ka}$ and ca. $205 \mathrm{ka}$. The skull is remarkable for its very great size, equivalent to the largest cave lions (Panthera spelaea [Goldfuss, 1810]) of Pleistocene Eurasia and much larger than any previously known lion from Africa, living or fossil. We hypothesize that this individual represents a previously unknown population or subspecies of lion present in the late Middle and Late Pleistocene of eastern Africa rather than being an indication of climate-driven size increase in lions of that time. This raises questions regarding the extent of our understanding of the pattern and causes of lion evolution in the Late Pleistocene.
\end{abstract}

\section{Introduction}

The image of the lion is pervasive in human culture from its earliest preserved expression in Paleolithic art (Clottes, 2003) to more 'modern' cultural manifestations (e.g., Disney's 'The Lion King'). In the scientific world lions are also a focus for attention (Schaller, 1972; Packer, 2015), and although not at present seriously threatened, except in India, lions are nevertheless of some conservation concern due to population declines in recent decades (Bauer et al., 2015). Yamaguchi et al. (2004) reviewed the broad-scale evolution of lions and Barnett et al. (2014) and Bertola et al. (2016) have discussed their recent population history. These publications have shown that lions originated in Africa and, apart from the small relict population in western India, they are confined to that continent in the present day. In the past, however, lions (whether subspecies of Panthera leo [Linnaeus, 1758] or closely related but distinct species, is a matter of debate) were arguably the mammalian species that, except for humans and our commensals, had the widest geographic distribution, extending from South Africa, across Eurasia and all the way to the eastern seaboard of North America. Ironically, the Late Pleistocene history of lions is far better known from phylogeography than from fossils, while the fossil record of lions is better known in North America and Eurasia than in Africa.

In Africa, the fossil record of lions comprises a few records from eastern African late Pliocene and early Pleistocene sites and a small number of Middle and Late Pleistocene sites in North and South Africa (Hendey, 1974; Klein, 1986; Werdelin and Peigné, 2010; Geraads, 2012). Practically nothing is known of lion evolution in eastern Africa during the Middle and Late Pleistocene. Herein, we describe and discuss a partial lion skull

\footnotetext{
$\dagger$ Francis H. Brown is deceased.

* Corresponding author.
}

from Natodomeri in northern Kenya, dated to ca. $196 \mathrm{ka}$ BP. The specimen is interesting not only as the first Kenyan lion fossil found in this time, but also because of its very great size, with measureable skull parameters showing it to be among the largest lion skulls known (including North American and Eurasian fossil lions, which are known to have been on average considerably larger than the extant lion).

Carnivore body mass (using lower carnassial length as proxy; see Van Valkenburgh, 1990) in relation to latitude and climate has been studied by Klein (1986) and Klein and Scott (1989). These authors found that carnivore body mass generally follows 'Bergmann's Rule,' with larger individuals occurring at higher latitudes and during colder phases of the glacial cycles. Lions were included in the latitudinal study and the results showed that the correlation between carnassial length and latitude (proxy for temperature) in lions was low but significant, and would have been higher if the sexes had been separated in the analysis. A later study on size fluctuation during glacial-interglacial cycles was carried out on spotted hyenas (Crocuta spp.), and lions may have conformed to the same pattern. With this background, finding the largest lion skull in Africa near the equator is unexpected.

Natodomeri is located between settlements at the Kenyan police posts of Kibish and Lokomarinyang. It lies in the Ilemi Triangle, a region that has been administered by Kenya since at least the 1950s. The name applies to a small ephemeral stream that cuts through a northeast-trending ridge at $\sim 425 \mathrm{~m}$ in elevation that is underlain by Pleistocene strata, and exposes these strata from $\sim 35.65^{\circ} \mathrm{E}$ to $35.80^{\circ} \mathrm{E}$ (Fig. 1).

\section{Geologic setting}

The Natodomeri area was first noted as being fossiliferous by K.W. Butzer, who visited it during work of the International 


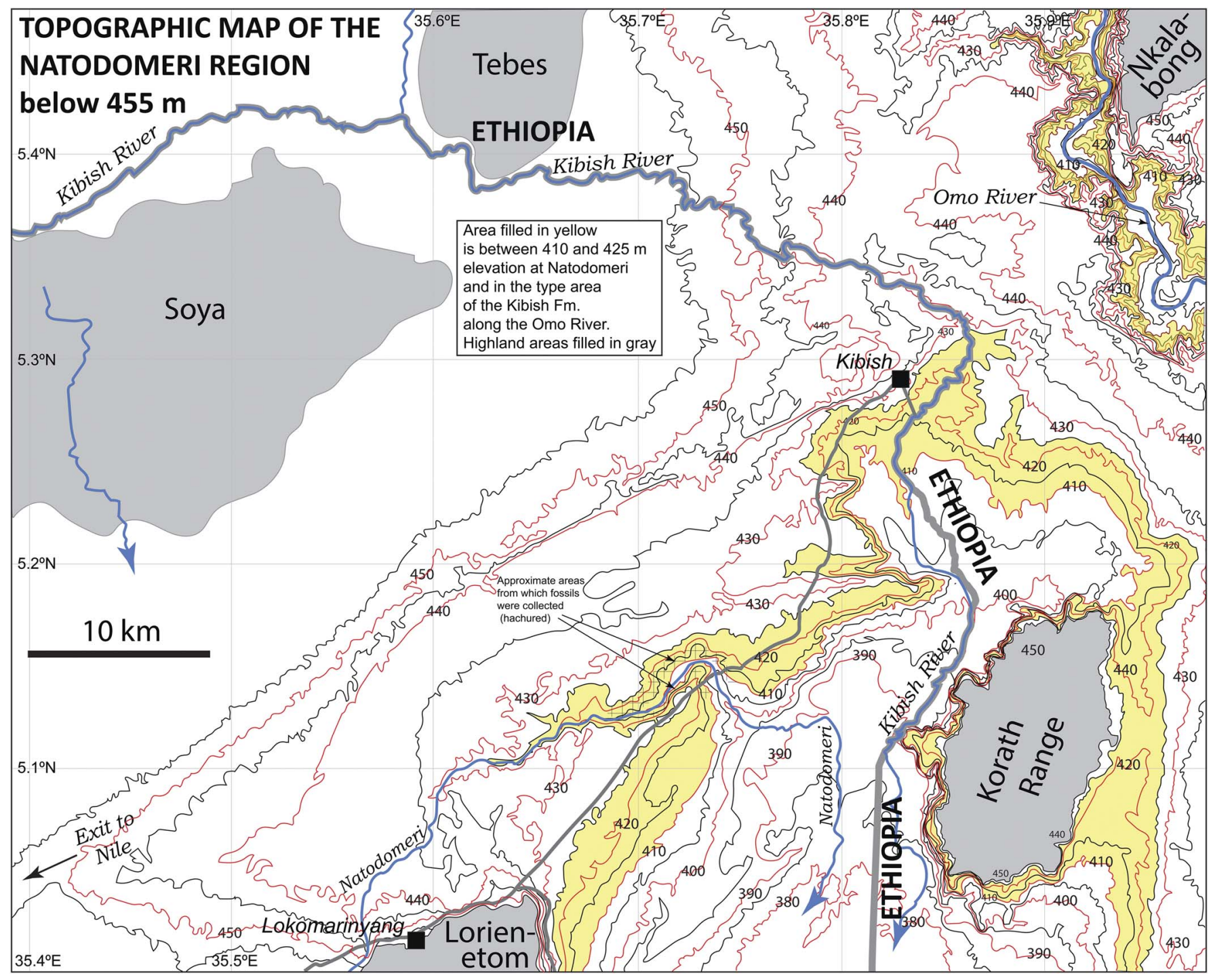

Figure 1. Map of the region near the Natodomeri fossil sites. Strata at these sites are at the same elevation as strata in the type area of the Kibish Formation in the NE corner of this map. Contours above $455 \mathrm{~m}$ are not shown.

Omo Research Expedition in 1968. The helicopter pilot, D. Woodhead, and Dr. Butzer's wife, Elisabeth, collected partial elephant molars at two sites designated Natodomeri I and Natodomeri II (K.W. Butzer and V.J. Maglio, unpublished manuscript, undated). Butzer located Natodomeri I at $5.1333^{\circ} \mathrm{N}$, $35.7773^{\circ} \mathrm{E}$, adjacent to the stream itself; and he placed Natodomeri II at $5.15^{\circ} \mathrm{N}, 35.8^{\circ} \mathrm{E}$, farther to the east. He correctly assigned both sites to the Kibish Formation. In the unpublished report, he described a section $13.2 \mathrm{~m}$ thick at Natodomeri I and a section $18.2 \mathrm{~m}$ thick at Natodomeri II. The upper four meters of the section at Natodomeri II were ascribed to Member IV of the Kibish Formation. Unionid shells from the upper part of the older section at Natodomeri II yielded a ${ }^{14} \mathrm{C}$ age $>35,000$ years (Butzer et al., 1972).

The section at Natodomeri is $<15 \mathrm{~m}$ thick and comprises principally sandstones, siltstones, and mudstones with discontinuous mollusk-bearing layers. Two of these molluskbearing layers are prominent near the base of the section, but even these are locally absent. Bivalves are especially prominent in these beds. One layer is especially rich in Etheria, and the other in unionids. Mollusk-bearing beds are also present higher in the section, and these contain gastropods in addition to the bivalves. Bedding is poorly expressed in most outcrops because the outcrops are weathered, but sparse cliff sections show that at least some of the units are thin bedded, with repeated small-scale fining-upward beds typical of deposits from annual floods, similar to those described by Brown and Fuller (2008) in the Kibish Formation, where they are particularly well developed at the base of Member II and the base of Member III.

The top of the section is defined by a tuff that is present in two layers (K16-1081), the lower of which is $0.3 \mathrm{~m}$ thick, overlain by a $5 \mathrm{~cm}$ sandstone containing Melanoides and small bivalves, followed by the upper layer that is $2 \mathrm{~m}$ thick (K16-1083). A Late Pleistocene or recent gravel 0.5-1 m thick makes up the top of this local section. Farther west, this tuff (K16-1076) is $1.9 \mathrm{~m}$ thick where exposed in a small gully.

Probable relations between the Kibish Formation in its type area, located $\sim 35 \mathrm{~km}$ northeast of Natodomeri, and at Natodomeri are shown in Figure 2. The KHS Tuff, present in both areas, forms a secure link between the two areas. In both 


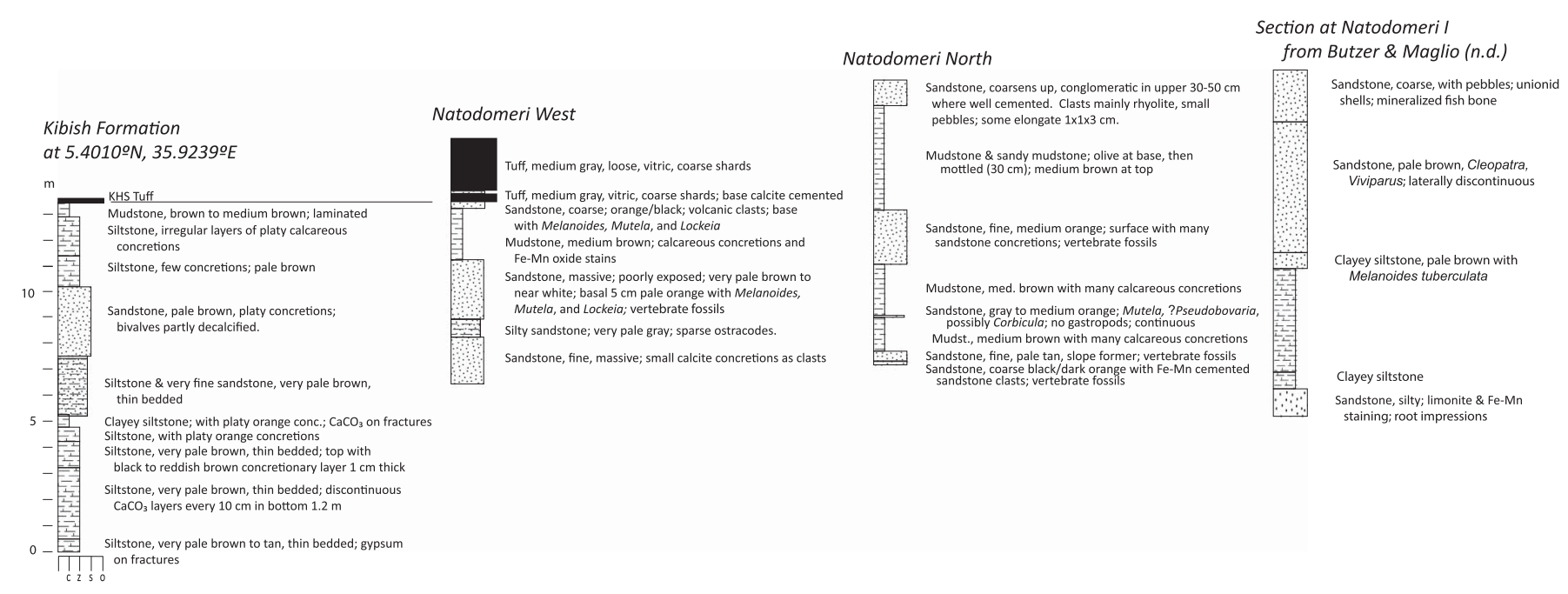

Figure 2. Stratigraphic relations between the Kibish Formation in its type area and at Natodomeri I, where KNM-ND 59673 was recovered.

places, the KHS Tuff is underlain by thin-bedded strata, which, in the type area of the Kibish Formation, lie disconformably on the strata of Member I. On this basis, the fossils from Natodomeri are ascribed to Member I of the Kibish Formation, the age of which Brown and Fuller (2008) estimated to be between $195 \mathrm{ka}$ and ca. $205 \mathrm{ka}$. Similar bivalve-bearing layers are present in both localities, but are absent in members II and III of the Kibish Formation in its type area.

The KHS Tuff is a very widespread unit (see Brown et al., 2012), correlative with the WAVT (Waidedo Vitric Tuff) in the Ethiopian Rift Valley and with a tuff at Kulkuletti, Ethiopia, for which Morgan and Renne (2008) regarded the most likely eruption age to be $183 \pm 10 \mathrm{ka}$. Brown et al. (2012) estimated its age at $172 \mathrm{ka}$, and this sets a minimum age on the section at Natodomeri. It is more difficult to place a maximum age on the section, but if the arguments concerning Kibish Member I in Brown et al. (2012) are correct, the entire section from which fossils were collected is between 195 and $205 \mathrm{ka}$ old.

At the time of deposition of Member I of the Kibish Formation, the region between the Hamar Kokke Range and Lorienetom was a vast plain $\sim 60-65 \mathrm{~km}$ wide. It was, we think, still uninterrupted by the Korath Range, for which we still have only one date of $91 \pm 15 \mathrm{ka}$ (Jicha and Brown, 2014) on one of the younger flows. Most deposition for the past 4 Ma has been on either side of a basement high that runs down the center of the low area (Mammo, 2012), with the Korath Range as a constructional feature near the north end of the basement high.

Deposition of Member I of the Kibish Formation took place on a delta of the Omo River when the northern margin of Lake Turkana was situated far north of its present position, and quite likely extended into the valley of the Usno River. Depending on the lake level, the position of the northern shoreline shifted by many tens of kilometers, as is shown by the location of a tuff of the Errum Formation (de Heinzelin, 1983) that correlates with a tuff in Member I of the Kibish Formation. Thus, in the ca. $10 \mathrm{ka}$ over which the member was deposited, the position the shoreline could have moved by at least $40 \mathrm{~km}$. This may seem extreme, but consider that in the last $10 \mathrm{ka}$, the northern margin of the lake has moved over $100 \mathrm{~km}$ southward, and between 1973 and 1989 the margin moved $16 \mathrm{~km}$ southward, so response to small changes in influent water can result in very rapid changes in the position of the shoreline.

At times, there was sufficient water in local low areas to support large populations of bivalves, but it is likely that these areas were highly localized because the bivalve-bearing units are discontinuous at approximately the same elevation laterally. It is likely that the region was heavily vegetated, as is the case of the Omo delta today, and thus could have supported large populations of herbivores. Higher ground was not far from Natodomeri because it is less than $15 \mathrm{~km}$ from the fossil sites to Lorienetom, and only a few $\mathrm{km}$ from the sites to areas $5 \mathrm{~m}$ or so above the highest known outcrops. The presence of stone artifacts suggests that at least during some intervals, Homo sapiens Linnaeus, 1758 inhabited the delta plain or delta margin itself.

\section{Materials and methods}

In 2014, F.K. Manthi was introduced to the Natodomeri sites by F.H. Brown. In 2015, a small team of the West Turkana Palaeo Project (WTPP) led by F.K. Manthi spent four days at the sites, during which 156 fossils were recovered, including the lion specimen under discussion here. The specimen, designated KNM-ND 59673, is housed in the Paleontology Section, National Museums of Kenya, Nairobi, Kenya. It has been compared with material housed in the osteological collections of the National Museums of Kenya and the Swedish Museum of Natural History, Stockholm, Sweden. Measurement data used here were collected by LW using digital calipers, complemented by data from the files of the late B. Kurtén, curated by LW (see Supporting Information).

Institutional abbreviations.-Institutions: KNM, National Museums of Kenya; NRM, Swedish Museum of Natural History.

\section{Systematic paleontology}

Anatomical abbreviations and measurements.-LP3, WP3, length and width, respectively, of third upper premolar; LP4, length of upper carnassial; WaP4 width at protocone of upper carnassial; m1 lower carnassial; PL, length of palate from anterior 
to upper incisors to posterior end of palatine; BL, basilar length from anterior to upper incisors to anterior end of foramen magnum.

Order Carnivora Bowdich, 1821

Family Felidae Fischer von Waldheim, 1817

Genus Panthera Oken, 1816

Panthera leo (Linnaeus, 1758)

Figure 3

Holotype.-None designated.

Remarks.-The taxonomy of Felidae recently has been revised by Kitchener et al. (2017).
Description of specimen.-The specimen (Fig. 3) is a heavily damaged and abraded partial skull of a mature, but not old (judging by dental wear) adult individual lacking the zygomatic arches, occipital region, and most of the basicranium. It includes most of the splanchnocranium, including premaxillae, maxillae, and palatine, although most bones are broken and sutures cannot be distinguished. Partial frontals and parietals are also present, including a part of the occipital crest. The basicranium retains posterior parts of the temporal and basisphenoid, including the damaged left mastoid process. Remains of the dentition include the right canine alveolus and damaged P3-P4, and roots of left canine and P3. The neurocranium is very slightly angled relative to the splanchnocranium. In anterior view, it can be seen that the

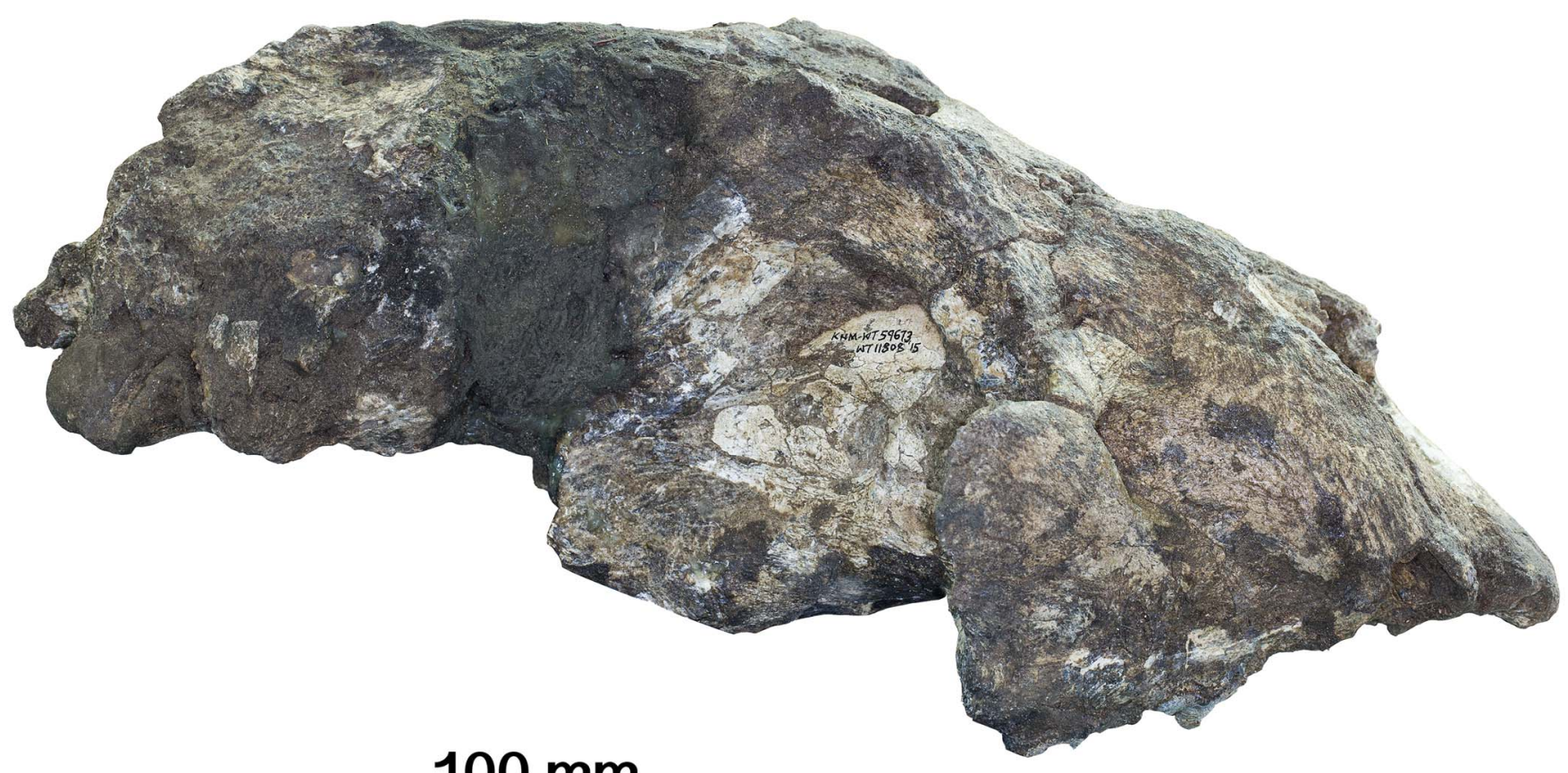

$100 \mathrm{~mm}$

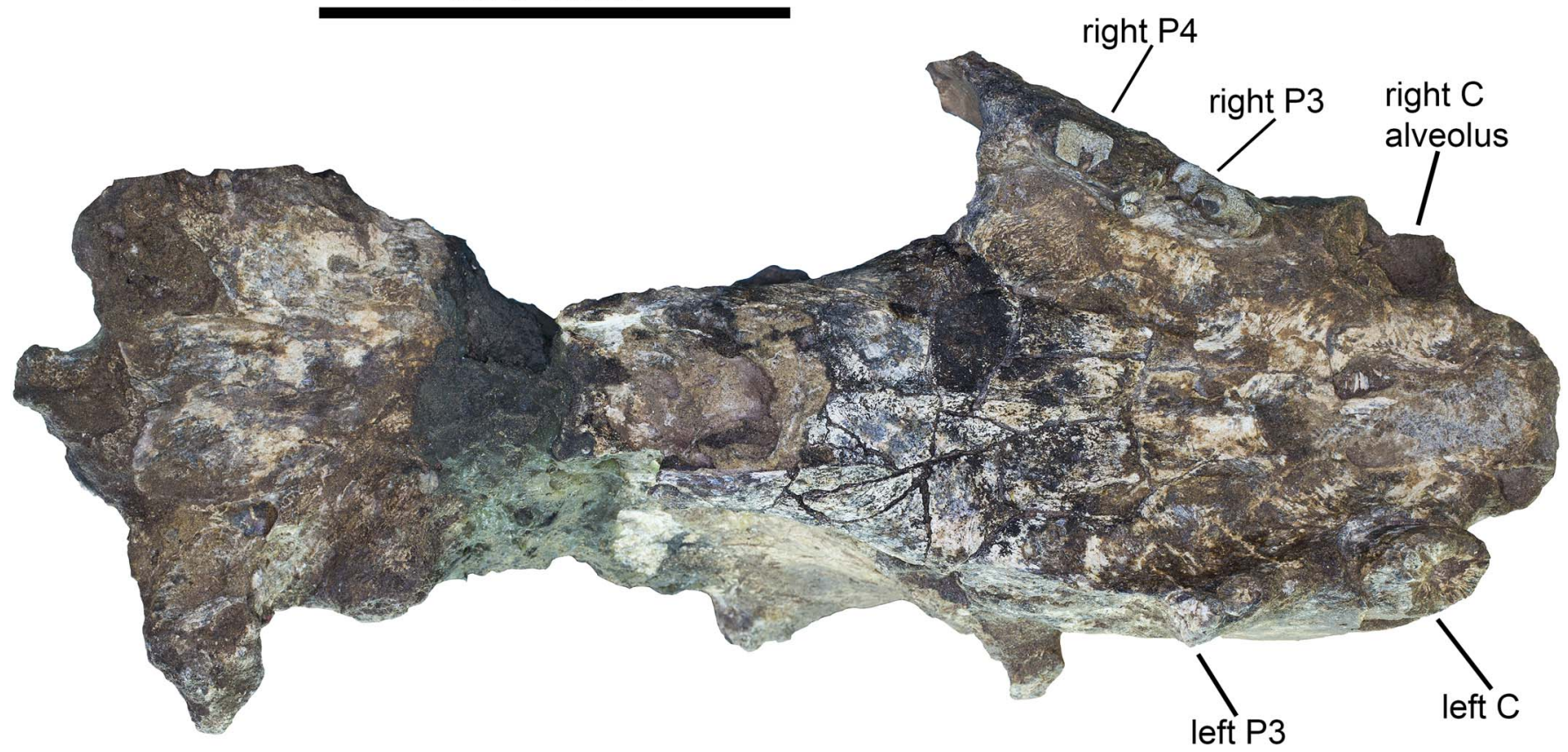

Figure 3. KNM-ND 59673, partial skull of Panthera leo from Natodomeri in (top) right lateral and (bottom) occlusal views. 
skull has been crushed transversely such that the right maxilla is angled medially (from dorsal to ventral).

The P3 has lost enamel on the mesiolingual edge and is damaged distally and distolingually. It is a robust tooth lacking a mesial accessory cusp. The main cusp is tall and slightly worn. The distal accessory cusp is prominent, set free from the main cusp, and followed distally by a cusplet on the distal cingulum. Enough remains of the tooth to obtain an accurate measure of length, while the width of the tooth can only be estimated. The P4 has sustained more damage than P3. The parastyle is chipped and broken, the protocone apex is broken, the paracone is nearly entirely lost except for a small part of the distolingual face, and the metastyle is buccally and distally damaged. Thus, for all intents and purposes, what remains of this tooth is its outline. However, the mesial end can be estimated by the better-preserved distal P3 and an assumption that the two teeth abut. The distal end can be estimated by the distal end of the alveolus, together with comparisons with extant lions and the difference between the distal end of the alveolus and distal end of $\mathrm{P} 4$ in those specimens.

Thus, just enough remains to obtain minimum estimates of LP3, WP3, LP4, WaP4, PL, and BL (see Abbreviations). These measurements in turn provide estimates of various aspects of the specimen's size and proportions (dental compared to cranial).

The specimen can be identified as felid because of the dental reduction, the relatively slender P3 with prominent distal accessory cusp, and the reduced protoconid on the upper carnassial. It can be identified as Felinae (conical-toothed cat) rather that Machairodontinae (sabretooth cat) based on the relatively robust upper cheek teeth and the oval upper canine. It can be identified as lion, Panthera leo, based on size, because lion is the largest of the Felinae in Africa and there is no reason based on the present material to hypothesize the presence of any previously unknown Felinae species on the continent in the late Middle Pleistocene.

Metric analysis.-The measurement data for the specimen are given in Table 1, together with our estimated uncertainty for each one. Summary statistics on the measurement data of the comparative samples are given in Table 2 and the raw data in Supporting Information. In the following we focus attention on two measurements: LP3 and PL, because these are the dental and cranial measurements, respectively, that are the most accurate, and, at the very least, were no smaller than the values given. The sample size for $P$. spelaea $\mathrm{PL}$ is very small $(\mathrm{N}=3)$. This has no important bearing on the conclusions, but to increase veracity $\mathrm{BL}$ is also included. This measurement is probably somewhat less accurate than PL, but is available for more specimens of P. spelaea.

Table 1. Measurement data for KNM-ND 59673. All measurements are minimum estimates. Uncertainty legend: $* * *$ fairly accurate, error estimated to $\leq 1 \%$; ** reasonably accurate, error estimated to $>1 \%, \leq 2 \%$; * poorly accurate: error estimated to $>2 \%$. Importantly, since all measurements are minimum estimates, the analyses will also provide minimum estimates of the overall size of the specimen. For abbreviations, see Material and Methods.

\begin{tabular}{lcc}
\hline Measurement & Value $(\mathrm{mm})$ & Uncertainty \\
\hline LP3 & 27.6 & $* *$ \\
LP4 & 38.3 & $*$ \\
PL & 196 & $* * *$ \\
BL & 380 & $* *$ \\
\hline
\end{tabular}

Table 2. Basic statistics for the three comparative taxa and four variables used in the paper. Raw data are given in Supplementary Information. For abbreviations, see Material and Methods.

\begin{tabular}{lccc}
\hline Group & Panthera leo & Panthera spelaea & Panthera atrox \\
\hline LP3 & & & \\
Mean & 24.0 & 27.0 & 27.3 \\
Standard deviation & 1.851 & 2.000 & 1.915 \\
Minimum & 21.2 & 23.5 & 23.9 \\
Maximum & 29.3 & 31 & 30.6 \\
N & 35 & 51 & 34 \\
LP4 & & & \\
Mean & 35.8 & 39.7 & 39.6 \\
Standard deviation & 2.000 & 2.653 & 2.488 \\
Minimum & 32.5 & 33.5 & 35.0 \\
Maximum & 40.0 & 44.7 & 45.0 \\
N & 35 & 54 & 36 \\
PL & & & \\
Mean & 142.2 & 178.3 & 176.7 \\
Standard deviation & 14.090 & 12.662 & 18.684 \\
Minimum & 116 & 167 & 143 \\
Maximum & 170 & 192 & 212 \\
N & 35 & 3 & 24 \\
BL & & & 333.6 \\
Mean & 268.7 & 326.1 & 34.034 \\
Standard deviation & 24.576 & 29.379 & 269 \\
Minimum & 220 & 291 & 405 \\
Maximum & 312 & 375 & 24 \\
N & 30 & 9 & \\
\hline
\end{tabular}

The selected measurements were analyzed using box-andwhisker plots (Fig. 4). The plot of LP3 (Fig. 4.1) shows extant $P$. leo to have a much shorter P3 than the two fossil species, P. atrox (Leidy, 1853) and P. spelaea. This is, of course, well known and corroborated by the t-tests (Table 3 ). The difference between the two fossil species is not significant. The length of the P3 of KNM-ND 59673 is greater than all but one of the extant lions in the comparative sample. The latter specimen is unfortunately of unknown origin. It should be noted that lions from South Africa are relatively underrepresented in the sample, and if Bergmann's Rule holds for lions, as suggested by Klein (1986), the largest lions would be expected to come from there. The South African lions included are among the largest in the sample. Figure 4.1 also shows that P3 length in KNM-ND 59673 lies within the $4^{\text {th }}$ quartile of both $P$. atrox and $P$. spelaea, although it is not among the very largest. Thus, P3 in KNM-ND 59673 is unusually long for an extant lion, but within the range of variation of the species.

The relationships seen for P3 length also largely apply to $\mathrm{P} 4$ length, although it is noteworthy that $\mathrm{P} 4$ is relatively much shorter than P3 in comparison to the other samples (Fig. 4.2). It is still longer than most specimens of $P$. leo, but does not lie outside the $95 \%$ confidence interval of that taxon. Relative to $P$. atrox and $P$. spelaea, the P4 of KNM-ND 59673 is well below median length.

The same relationships between the comparative samples apply to the variables PL and BL as to LP3 (Fig. 4.3, 4.4). These measurements in KNM-ND 59673 are, however, substantially larger than those of any extant lion. Compared to P. spelaea, KNM-ND 59673 is larger than all available specimens with a measurable PL $(\mathrm{N}=3$ only) and $\mathrm{BL}(\mathrm{N}=9)$. Compared to the much larger samples of $P$. atrox, KNM-ND 59673 is larger than all but two for both PL and BL. These comparisons show that in terms of skull length, KNM-ND 59673 is of the size of a large specimen of $P$. atrox, which in turn was a much larger species than the extant $P$. leo. 

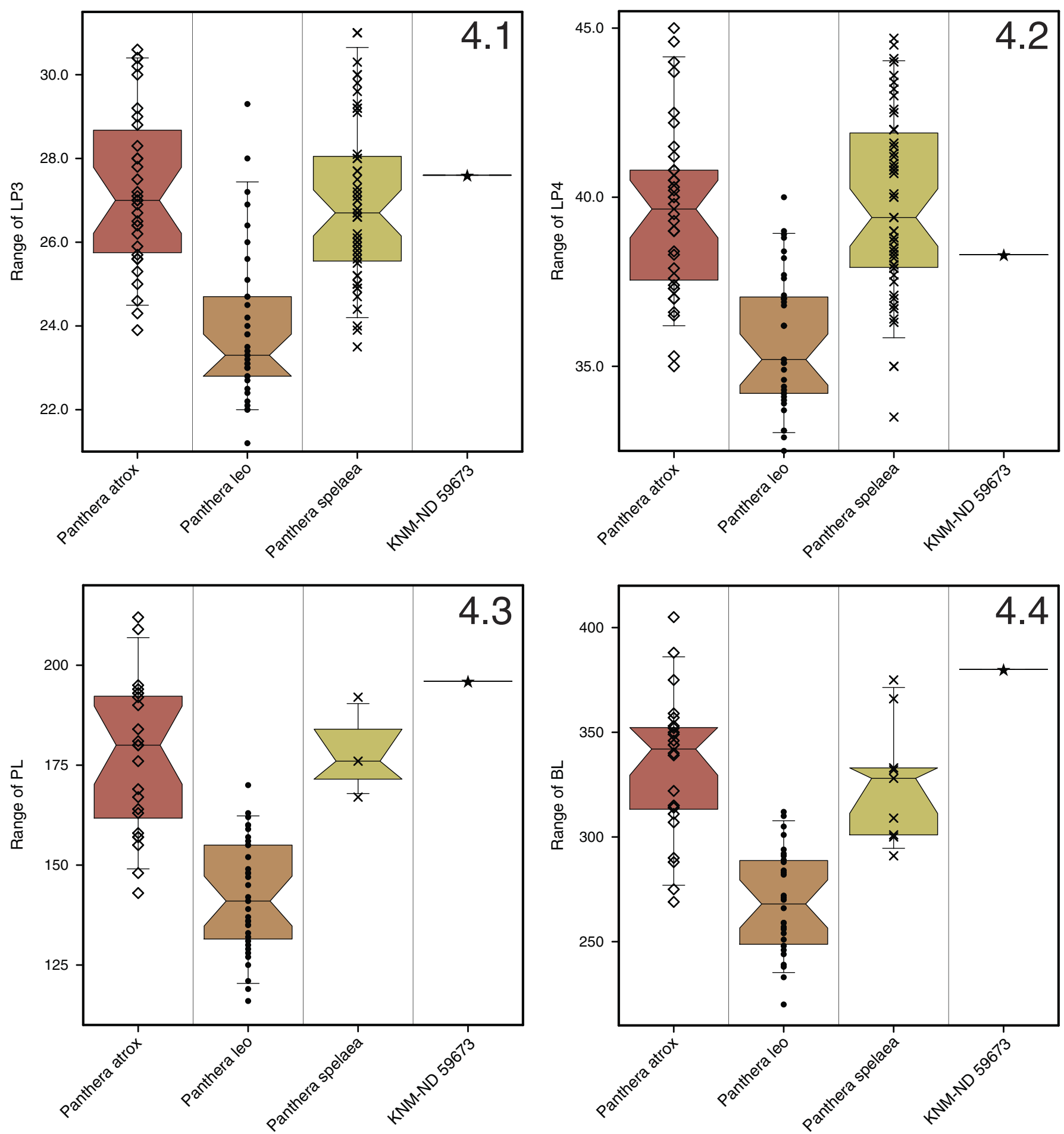

Figure 4. Box-and-whisker plots comparing KNM-ND 59673 and Panthera atrox, extant Panthera leo, and Panthera spelaea for selected metric variables. (4.1) Upper third premolar length (LP3); (4.2) upper carnassial length (LP4); (4.3) palate length (PL); and (4.4) basilar length (BL). The 'waist' of each polygon represents the median; the shaded boxes above and below the median are the $2^{\text {nd }}$ and $3^{\text {rd }}$ quartiles; the whiskers are set at the $5^{\text {th }}$ and $95^{\text {th }}$ percentiles; all specimens included are represented by individual symbols.

In summary, the size of KNM-ND 59673 greatly exceeds that of extant lions for skull length and is among the largest for P3 length. Taken together, these observations indicate that skull length was larger relative to P3 length than in extant lions and possibly also the extinct species, though the latter is more difficult to demonstrate.

\section{Discussion}

The lion fossil described herein is an isolated find. Despite this, its great size and the geographic location of the site require some discussion of the conditions that could have led to these circumstances. The BL of KNM-ND 59673 lies more than 4.5 
Table 3. Results of pairwise t-tests for difference of means of the three comparative samples. All tests were two-tailed and for equal variances except the test incorporating $P$. atrox and the variables PL and BL, which were for unequal variances. The null hypothesis is that means were equal and significant p-values indicate that the hypothesis is overturned. Values of $\mathrm{p}$ are shown below the diagonals and the significance level above the diagonals. $\mathrm{NS}=$ not significant; for other abbreviations, see Material and Methods.

\begin{tabular}{|c|c|c|c|}
\hline LP3 & P. leo & P. spelaea & P. atrox \\
\hline P.leo & - & $* * *$ & $* * *$ \\
\hline P. spelaea & $\mathrm{p} \ll 0.0001$ & - & NS \\
\hline $\begin{array}{l}\text { P. atrox } \\
\text { LP4 }\end{array}$ & $\mathrm{p} \ll 0.0001$ & $\mathrm{p}=0.511$ & - \\
\hline P. leo & - & $* * *$ & $* * *$ \\
\hline P. spelaea & $\mathrm{P} \ll 0.0001$ & - & NS \\
\hline $\begin{array}{l}P . \text { atrox } \\
\text { PL }\end{array}$ & $\mathrm{P} \ll 0.0001$ & $P=0.797$ & - \\
\hline P. leo & - & $*$ & $* * *$ \\
\hline P. spelaea & $\mathrm{p}=0.0284$ & - & NS \\
\hline P. atrox & $\mathrm{p} \ll 0.0001$ & $\mathrm{p}=0.852$ & - \\
\hline P. leo & - & $* * *$ & $* * *$ \\
\hline P. spelaea & $\mathrm{P}=0.000204$ & - & NS \\
\hline P. atrox & $\mathrm{P} \ll 0.0001$ & $P=0.540$ & - \\
\hline
\end{tabular}

standard deviations from the mean of our sample of modern lion, so the specimen cannot be reasonably attributed to the modern form. Alternatively, the great size of KNM-ND 59673 can be accounted for in three ways: (1) it represents an extinct species distinct from, but closely related to, Panthera leo; (2) it represents the result of body size tracking climate change in the Middle and Late Pleistocene, but does not represent a distinct population or subspecies; (3) it represents an extinct, distinct population or subspecies that was substantially larger than any modern population or subspecies within P. leo.

None of these alternatives can be definitively ruled out. However, alternative 1 must be considered very unlikely given the fossil record of lions in Africa, as summarized in Yamaguchi et al. (2004). Fossil lions dating back as far as 2 Ma are morphologically indistinguishable from modern lions (Werdelin and Lewis, 2005, 2013; Werdelin and Peigné, 2010; Werdelin and Dehghani, 2011) and, except for KNM-ND 59673, fall within the size range of the modern species, taking into account its entire geographic range. The fossil record is notoriously fickle, but any extinct and much larger species would be expected to have a significant temporal extent (measured in hundreds of thousands of years at least), and although sampling in the latest Middle and Late Pleistocene is comparatively poor, that of the East African (and particularly Kenyan) early Pleistocene is quite good, which makes it unlikely that a such a distinct species of lion would have left no trace in the known fossil record.

With regard to alternative 2, the work of Klein (1986) showed that there is some change in $\mathrm{m} 1$ size (the proxy used for body size) with latitude in modern lions, with lions at high latitude (and colder climate) being somewhat larger than lions living closer to the equator. The difference is slight, however ( 3\%; see Klein, 1986, fig. 17). In the present case, the difference in BL is $>40 \%$ and it is highly unlikely that climate differences between present-day Kenya and that of 200,000 years ago could explain such a large difference. This is especially true because the age of the Natodomeri lion specimen places it close to the end of Marine Isotope Stage 7, at a time when climate was cooler than today but still far from glacial. It could be argued that $\mathrm{P} 3$ and $\mathrm{P} 4$ length differ much less from extant lions than $\mathrm{BL}$ in KNM-ND 59673, and thus that skull size might be more susceptible to size increase with cold climate than dental size. Our data do indeed show allometry, in that BL increases faster than LP4 with increasing size (slope of reduced major axis regression 1.641 for $\log _{10}$ data). However, even with this allometry accounted for, a modern lion with LP3 of $38.3 \mathrm{~mm}$ would be expected to have a BL of $\sim 300-310 \mathrm{~mm}$, not the $380 \mathrm{~mm}$ that is the case with the specimen under study. We thus consider a purely climate-driven explanation for the great size of the specimen unlikely.

Alternative 3, although not at present susceptible to proof, seems the most plausible of the three. Phylogeographic studies of extant lion (Barnett et al., 2014; Bertola et al., 2016) indicate that extant lion haplotypes diversified 120.2-384.8 ka, which brackets the date for the Natodomeri lion. If the mean divergence estimate of $244.8 \mathrm{ka}$ is correct (Bertola et al., 2016:fig. 3), the Natodomeri lion could hypothetically represent a haplotype that was sister taxon to all extant lion haplotypes. Interestingly, Natodomeri lies in the overlap between the two major haplogroups ('north' and 'south') of Bertola et al. (2016). Therefore, alternative but somewhat less likely hypotheses are that the Natodomeri lion was sister taxon to all extant lions within either the 'south' group of Bertola et al. (2016), the diversification of which is dated to $90.3-300.6 \mathrm{ka}$ (mean: $189.2 \mathrm{ka}$ ) or the 'north' group, dated to $71.6-239.7 \mathrm{ka}$ (mean: $147.6 \mathrm{ka}$ ).

As noted, fossils from the late Middle and Late Pleistocene are poorly documented in eastern Africa and since a genetically distinct population or subspecies could be temporally quite ephemeral the likelihood that it would be sampled is much reduced from that of a species. That such a population may have existed could be due to greater biomass of megafauna in the late Middle and Late Pleistocene than at present, sustaining a population of very large lions. Occurrence of abundant megafauna, such as the giant buffalo Syncerus antiquus (Duvernoy, 1851) (see Faith, 2014 for a discussion of Late Pleistocene extinctions in Africa) at this time may also have led to the evolution of a larger lions to exploit this resource more extensively than today.

\section{Conclusions}

This paper describes KNM-ND 59673, from the late Middle Pleistocene of Natodomeri, northeastern Kenya, the partial skull of a lion of much greater size than any alive today. This skull represents the first indication of the existence of a population of giant lions in the late Middle and Late Pleistocene of eastern Africa, perhaps occasioned by the presence of greater megafaunal biomass than today.

The find of KNM-ND 59673 reminds us that the Middle and Late Pleistocene of eastern Africa are still poorly studied and that surprises will still occur as sampling improves.

\section{Acknowledgments}

We thank the Government of Kenya for permission to work at Natodomeri. We also thank the National Museums of Kenya for supporting this project. The Turkana County administration and the Turkana people in the Natodomeri area provided invaluable 
support to the project. We thank N. Yamaguchi and one anonymous reviewer for valuable comments on the manuscript. This project would not have been possible without the dedication of the WTPP crewmembers. Funding for this project was provided by the Leakey Foundation and the Palaeontological Scientific Trust (PAST) of South Africa. Work by LW in Africa is funded by the Swedish Research Council.

\section{Accessibility of supplemental data}

Data available from the Dryad Digital Repository http://doi.org/ 10.5061/dryad. 279n4

\section{References}

Barnett, R., Yamaguchi, N., Shapiro, B., Ho, S.Y.W., Barnes, I., Sabin, R. Werdelin, L., Cuisin, J., and Larson, G., 2014, Revealing the maternal demographic history of Panthera leo using ancient DNA and a spatially explicit genealogical analysis: BMC Evolutionary Biology, v. 14, no. 70, 11 p. doi: $10.1186 / 1471-2148-14-70$

Bauer, H., Chapron, G., Nowell, K., Henschel, P., Funston, P., Hunter, L.T., Macdonald, D.W., and Packer, C., 2015, Lion (Panthera leo) populations are declining rapidly across Africa, except in intensively managed areas: Proceedings of the National Academy of Sciences of the United States of America, v. 112, p. 14894-14899.

Bertola, L.D., Jongbloed, H., van der Gaag, K.J., de Knijff, P., Yamaguchi, N., Hooghiemstra, H., Bauer, H., Henschel, P., White, P.A., Driscoll, C.A., Tende, T., Ottosson, U., Saidu, Y., Vrieling, K., and de Iongh, H.H., 2016, Phylogeographic Patterns in Africa and High Resolution Delineation of Genetic Clades in the Lion (Panthera leo): Scientific Reports, v. 6, Art. No. 30807. doi: $10.1038 /$ srep30807

Bowdich, T.E., 1821, An Analysis of the Natural Classifications of Mammalia for the Use of Students and Travelers: Paris, J. Smith, 115 p.

Brown, F.H., and Fuller, C.R., 2008, Stratigraphy and tephra of the Kibish Formation, southwestern Ethiopia: Journal of Human Evolution, v. 55, p. 366-403.

Brown, F.H., McDougall, I., and Fleagle, J.G., 2012, Correlation of the KHS Tuff of the Kibish Formation to volcanic ash layers at other sites, and the age of early Homo sapiens (Omo I and Omo II): Journal of Human Evolution, v. 63 , p. $577-585$.

Butzer, K.W., Isaac, G.L., Richardson, J.L., and Washbourn-Kamau, C., 1972, Radiocarbon dating of East African lake levels: Science, v. 175, p. 1069-1076.

Clottes, J., 2003, Return to Chauvet Cave. Excavating the Birthplace of Art: The First Full Report: London, Thames \& Hudson, 225 p.

De Heinzelin, J., ed., 1983, The Omo Group, archives of the international Omo Research Expedition: Tervuren, Musée Royal de l'Afrique Centrale, Annales, Série in $8^{\circ}$, v. 85,365 p.

Duvernoy, G.L., 1851, Note sur une espèce fossile de Buffle fossile (Bubalus (Arni) antiquus) découverte en Algérie: Compte rendu hebdomadaire des séances de l'Académie des Sciences de Paris, v. 33, p. 595-597.

Faith, J.T., 2014, Late Pleistocene and Holocene mammal extinctions on continental Africa: Earth-Science Reviews, v. 128, p. 105-121.

Fischer von Waldheim, G., 1817, Adversaria Zoologica, fasciculus primus: Mémoires de la Société des Naturalistes de Moscou, v. 5, p. 357-446.

Geraads, D., 2012, The Faunal Context of Human Evolution in the Late Middle/Late Pleistocene of Northwestern Africa, in Hublin, J.-J., and McPherron, S.P., eds., Modern Origins: A North African Perspective: Dordrecht, Springer, p. 49-60.
Goldfuss, G.A., 1810, Die Umgebungen von Muggendorf. Ein Taschenbuch für Freunde der Natur und Alterumskunde: Erlangen, J.J. Palm, 389 p.

Hendey, Q.B., 1974, The late Cenozoic Carnivora of the south-western Cape Province: Annals of the South African Museum, v. 63, p. 1-369.

Jicha, B. R., and Brown, F. H., 2014, An age on the Korath Range, Ethiopia and the viability of ${ }^{40} \mathrm{Ar} /{ }^{39} \mathrm{Ar}$ dating of kaersutite in Late Pleistocene volcanics: Quaternary Geochronology, v. 21, p. 53-57.

Kitchener, A.C., Breitenmoser-Würsten, C., Eizirik, E., Gentry, A., Werdelin, L., Wilting, A., Yamaguchi, N., Abramov, A., Christiansen, P., Driscoll, C., Duckworth, W., Johnson, W., Luo, S.-J., Meijaard, E., O’Donoghue, P., Sanderson, J., Seumour, K., Bruford, M., Groves, C., Hoffmann, M., Nowell, K., Timmons, Z., and Tobe, S., 2017, A revised taxonomy of the Felidae. The final report of the Cat Classification Task Force of the IUCN Cat Specialist Group: Cat News Special Issue, v. 11 , p. $1-80$.

Klein, R.G., 1986, Carnivore Size and Quaternary Climatic Change in Southern Africa: Quaternary Research, v. 26, p. 153-170.

Klein, R.G., and Scott, K., 1989, Glacial/Interglacial size variation in fossil spotted hyenas (Crocuta crocuta) from Britain: Quaternary Research, v. 32, p. 88-95.

Leidy, J., 1853, Description of an extinct species of American lion: Felis atrox: Transactions of the American Philosophical Society, New Series, v. 10, p. 319-321.

Linnaeus, C., 1758, Systema Naturae per Regna Tria Naturae: Secundum Classes, Ordines, Genera, Species, cum Characteribus, Differentiis, Synonymis, Locis, $10^{\text {th }}$ ed.: Stockholm, Laurentius Salvius, $824 \mathrm{p}$.

Mammo, T., 2012, Analysis of gravity field to reconstruct the structure of Omo basin in SW Ethiopia and implications for hydrocarbon potential: Marine and Petroleum Geology, v. 29, p. 104-114.

Morgan, L.E., and Renne, P.R., 2008, Diachronous dawn of Africa's Middle Stone age: new ${ }^{40} \mathrm{Ar} /{ }^{39} \mathrm{Ar}$ ages from the Ethiopian Rift: Geology, v. 32, p. 967-970.

Oken, L., 1816, Lehrbuch der Naturgeschichte. Dritter Theil. Zoologie: Jena, August Schmid und Comp., $1270 \mathrm{p}$.

Packer, C., 2015, Lions in the Balance: Man-Eaters, Manes, and Men with Guns: Chicago, University of Chicago Press, $355 \mathrm{p}$.

Schaller, G.B., 1972, The Serengeti Lion. A Study of Predator-Prey Relations: Chicago, The University of Chicago Press, 504 p.

Van Valkenburgh, B., 1990, Skeletal and dental predictors of body mass in carnivores, in Damuth, J., and MacFadden, B.J., eds., Body Size in Mammalian Paleobiology: Estimation and Biological Implications: Cambridge, Cambridge University Press, p. 181-205.

Werdelin, L., and Dehghani, R., 2011, Carnivora, in Harrison, T., ed., Paleontology and Geology of Laetoli: Human Evolution in Context. Volume 2: Fossil Hominins and the Associated Fauna: New York, Springer, p. $189-232$.

Werdelin, L., and Lewis, M.E., 2005, Plio-Pleistocene Carnivora of eastern Africa: species richness and turnover patterns: Zoological Journal of the Linnean Society, v. 144, p. 121-144.

Werdelin, L., and Lewis, M.E., 2013, Koobi Fora Research Project, Volume 7: The Carnivora: San Francisco, California Academy of Sciences, $333 \mathrm{p}$.

Werdelin, L., and Peigné, S., 2010, Carnivora, in Werdelin, L., and Sanders, W.J., eds., Cenozoic Mammals of Africa: Berkeley, University of California Press, p. 609-663

Yamaguchi, N., Cooper, A., Werdelin, L., and Macdonald, D.W., 2004 Evolution of the mane and group-living in the lion (Panthera leo): a review: Journal of Zoology, v. 263, p. 329-342.

Accepted 17 June 2017 